\title{
Reactive transport modelling of cement-groundwater-rock interaction at the Grimsel Test Site
}

\author{
M. Carme Chaparro ${ }^{\mathrm{a}, \mathrm{c}, *}$, Maarten W. Saaltink ${ }^{\mathrm{b}, \mathrm{c}}$, Josep M. Soler ${ }^{\mathrm{a}, \mathrm{c}}$ \\ ${ }^{a}$ Institute of Enviromental Assessment and Water Research (IDAEA), CSIC, Jordi \\ Girona 18, 08034 Barcelona, Catalonia, Spain \\ ${ }^{b}$ Department of Civil and Environmental Engineering, Universitat Politècnica de \\ Catalunya (UPC), Jordi Girona 1-3, 08034 Barcelona, Catalonia, Spain \\ ${ }^{c}$ Associated Unit: Hydrogeology Group (UPC-CSIC)
}

\begin{abstract}
An in situ experiment at the Grimsel Test Site (Switzerland) to study water-cement-rock interaction in fractured granite was modelled. It consisted of a hardened cement source in a borehole intersecting a water conducting fracture. Grimsel groundwater was injected into this borehole. Two other boreholes at about $0.56 \mathrm{~m}$ and $1.12 \mathrm{~m}$ from the emplacement borehole were used to monitor the evolution of water composition for 5 years. The modelling approach was based on a 1D radial model for the emplacement borehole and a small volume of rock (fault gouge) around it, and a 2D model for the rest of the domain. The results of the $1 \mathrm{D}$ model were used as input for the $2 \mathrm{D}$ model. Both models showed dissolution of the fault gouge minerals. Results from the 1D model showed dissolution of portlandite in the cement with an increase in porosity. The $2 \mathrm{D}$ model showed a reduction in porosity in the fault gouge due to mineral precipitation. Near the emplacement borehole ettringite precipitated. At the center of the plume there was precipitation of $\mathrm{C}-\mathrm{A}-\mathrm{S}-\mathrm{H}$ and hydrotalcite. At the edge of the hyperalkaline plume calcite, hydrotalcite and illite precipitated.
\end{abstract}

Keywords: reactive transport, cement, hyperalkaline plume, numerical

\footnotetext{
*Corresponding author. Present address: IDAEA-CSIC, Jordi Girona 18-26, 08034 Barcelona, Catalonia, Spain.

Email address: mcarme.chaparro@gmail.com (M. Carme Chaparro)
} 
model

\section{Introduction}

Ordinary Portland Cement (OPC) is frequently used for radioactive waste storage as a part of the engineered barrier system or as structural support in the host rock. The cement pore water is hyperalkaline $(\mathrm{pH}>13)$ and can react chemically with the host rock of the repository. Several studies have investigated the interaction between the cement, the hyperalkaline plume and the host rock (Read et al., 2001; Savage et al., 2002; Gaucher et al., 2004; Hoch et al., 2004; Sánchez et al., 2006; Mäder et al., 2006; Pfingsten et al., 2006; De Windt et al., 2008; Soler and Mäder, 2010; Savage et al., 2011; Soler, 2013; Kosakowski and Berner, 2013; Moyce et al., 2014; Soler, 2016; Martin et al., 2016). In general, they found a reduction in porosity due to precipitation of secondary minerals. Our study was part of the LCS Project (Long-Term Cement Studies), with the objective of studying the water-cement-rock interaction and their effect on water flow and solute transport properties. To do so, an in situ experiment was started in 2009 at the Grimsel Test Site underground rock laboratory (Switzerland, www.grimsel.com). First, a tracer experiment was performed to characterize the initial flow and transport properties of the rock (granite) around the test site. Afterwards, the in situ experiment was performed. A hardened cement source was installed in a borehole intersecting a water conducting fracture. Then, Grimsel groundwater was circulated or injected into this borehole and the evolution of water composition in the fracture was monitored for 5 years. A preliminary reactive transport model corresponding to the formation of a high-pH plume and its interaction with the rock was reported by Saaltink and Soler (2016). The conceptual model considered a 1D radial model for the emplacement borehole and a small volume of surrounding rock (fault gouge), and a 2D model for the rest of the domain. The results of the 1D model were used as input for the 2D model. The objective of our study is to develop a qualitative and partially quantitative understanding of the geochemical processes that took place during the experiment. To do so, we followed the same conceptual model as Saaltink and Soler (2016), with a relatively simple flow model, which was based on an initially homogeneous fracture. The results of the numerical model were compared with the available experimental data. We used the monitoring data of flow rates and solution composition at the emplacement, observation and extraction boreholes, the data from 
post-mortem analysis of the cement made by the Swiss Federal Laboratories for Materials Science and Technology (EMPA) and the mineralogical analysis from samples next to the emplacement borehole made by the British Geological Survey (BGS).

\section{In situ Experiment}

The experiment took place at the Grimsel underground rock laboratory (Switzerland). Pre-hardened Ordinary Portland Cement hollow cylindrical segments were emplaced in a borehole (emplacement borehole) intersecting a water-conducting fracture. Starting from the center, the borehole contained an inner dummy (inert cylinder) followed by the cement and a water-filled gap. Two other boreholes (called observation and extraction boreholes) were placed at 0.56 and 1.12 meters away from the emplacement borehole. There were no cement pieces in the observation and extraction boreholes. These boreholes were instrumented with multiple packer systems to capture the effluent from a specific fracture. A skin of low permeability was assumed to surround the boreholes (Figure 1). Grimsel groundwater was circulated and injected in the emplacement borehole. Water was extracted at the observation and extraction boreholes and the chemical compositions of the different solutions were monitored. After the injection was started in the emplacement borehole, elevated $\mathrm{pH}$ and solute concentrations reflecting interaction with the cement were observed in the observation and extraction boreholes.

\section{Numerical Model}

\subsection{Modelling approach}

Our conceptual model considered only a simple homogenous fracture of $5 \mathrm{~mm}$ thickness, taking into account the reactions that could have occurred during the interaction between the cement, Grimsel groundwater and the fault gouge filling the fracture. The simulations were carried out using the Retraso-CodeBright software package (Saaltink et al., 2004). The modelling approach considered two different models (1D radial and 2D). First, a detailed 1D radial model simulated the emplacement borehole (hardened cement paste) together with the surrounding skin (Figure 1b). Then, the results of this model (solute concentrations at the outer boundary of the skin of the emplacement borehole) were used as input for the 2D model that simulated the fracture plane at the scale of all three boreholes (emplacement, 
observation and extraction). The conceptual model assumed that during the initial test period without injection of water in the borehole the permeability in the skin was low enough to avoid flow of water in that zone. It also assumed that when water was injected, the flow in the skin was only affected by this injection (radial flow) and was not affected by the extraction in the other boreholes.

a)

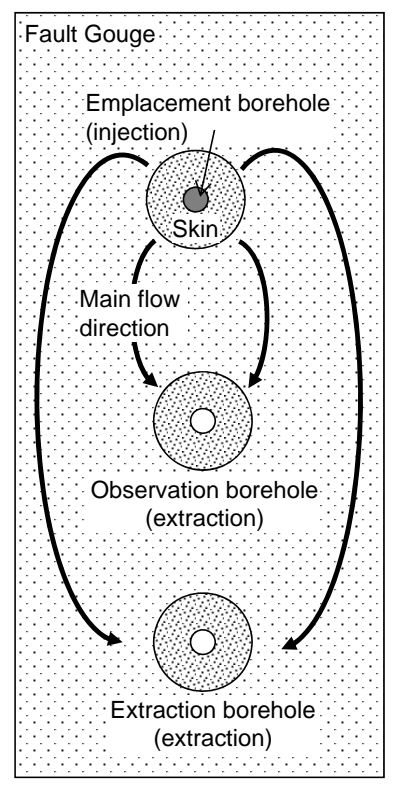

b)
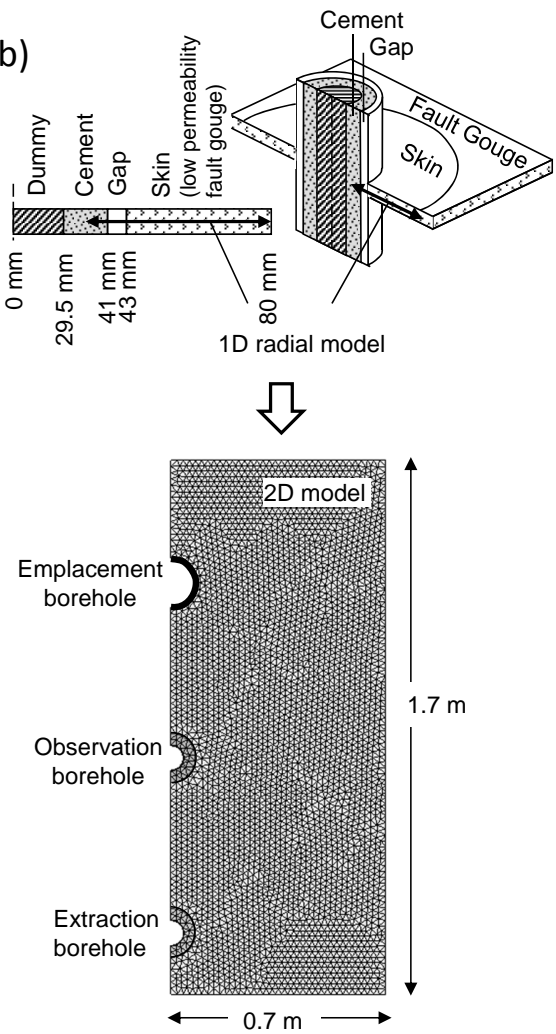

Figure 1: Conceptual model a) Plan view of the fracture plane with the three boreholes; lines indicate the main direction of flow b) Geometry of the 1D and 2D models.

\subsection{Geometry and mesh}

The geometry of the 1D radial model reflected the hardened cement paste, the existing gap between cement and rock and the skin with total length (radius) of $80 \mathrm{~mm}$ (Figure 1b). In the model, a thicker and thinner cement zone (from 35 to $41 \mathrm{~mm}$ ) was finally considered, to be able to correctly simulate the observed alteration of the cement, which affected both the inner and outer 
surfaces. In this fashion, the increased cement surface could be included in the model. The domain was discretized into 97 1D finite elements with sizes ranging from $0.1 \mathrm{~mm}$ near the gap between cement and skin to $1.5 \mathrm{~mm}$ near the outer boundary. The model considered that the width of the fracture was $5 \mathrm{~mm}$, according to observations at the site of several individual fractures of millimetric aperture. The geometry of the 2D model represented the fault gouge filling the fracture and the three boreholes. Neither the cement in the emplacement borehole nor the skin of the emplacement borehole were considered explicitly. The concentrations at the outer end of the 1D model were used as a time-dependent boundary condition for the 2D model (skinfracture interface). For the observation and extraction boreholes, their gaps and skins were explicitly modelled. The mesh refinement was studied, because results could depend on the spatial discretization (Marty et al., 2009). Nevertheless, we did not observe significant qualitative changes in our case with the implemented mesh. The finite element mesh consisted of triangular elements with a size of about $2 \mathrm{~cm}$. The possible natural gradients could be neglected due to the high flow rates at these boreholes. This means that the 2D model assumed that the flow of water was only affected by the injection or extraction flow rates at the three boreholes (emplacement, observation and extraction) and that the system was symmetrical with respect to the line crossing the centre of the three boreholes. Only half of the domain had to be modelled (Figure 1b). Only the period when water was injected into the emplacement borehole was taken into account in this $2 \mathrm{D}$ model. The initial diffusion period (August 2009 to October 2010) was not considered, because this period had no measurable effect on the water chemistry at the observation and extraction boreholes.

\subsection{Transport parameters}

Table 1 displays the transport parameters of the materials used in the $1 \mathrm{D}$ and $2 \mathrm{D}$ models. Intrinsic permeabilities of the skin and fault gouge were taken from Manette et al. (2015), which were estimated from pumping and tracer tests. The permeability of the cement had no effect because there was no flow of water through the cement paste, and the permeabilities for the gaps were high enough to maintain a homogeneous pressure within each gap. The porosity of the gaps is 1, i.e., it was assumed to only contain water. However, the total volume of water in the circulation system (tank, tubing, gap) was taken into account by rescaling the porosity of the gap by multiplying the real porosity by the total water volume divided by the modelled gap volume. The 
same was done for the cement which had a thickness larger than the modelled fracture. The porosity of cement paste was based on the results of the cement source characterization. The porosity for the fault gouge was taken from Soler and Mäder (2010) for a laboratory core infiltration experiment with a sample from the same shear zone region at Grimsel Test Site. The diffusion coefficient of the cement paste was calibrated based on the thickness of the alteration zone in the cement (portlandite dissolution and porosity increase). Diffusion coefficient and dispersivity of the gaps were sufficiently high to ensure perfect mixing within the gap. In the skin and fault gouge typical values of the diffusion coeficient were used. The dispersivities of the skin were from Manette et al. (2015), which were estimated from tracer tests. The dispersivity assigned to the cement paste had no effect because there was no flow of water through the cement paste.

Table 1: Parameters of the materials used in the 1D and 2D models.

\begin{tabular}{lllllll}
\hline & $k\left(\mathrm{~m}^{2}\right)$ & $\phi_{\text {real }}$ & $\phi_{\text {rescaled }}$ & $D_{\mathrm{p}}\left(\mathrm{m}^{2} \mathrm{~s}^{-1}\right)$ & $\alpha_{L}(\mathrm{~m})$ & $\alpha_{T}(\mathrm{~m})$ \\
\hline 1D model & & & & & & \\
Cement & $8.0 \times 10^{-18}$ & 0.47 & 121.49 & $2.0 \times 10^{-11}$ & 0.002 & - \\
Gap empl. & $3.0 \times 10^{-10}$ & 1.0 & 1842.78 & $1.0 \times 10^{-5}$ & 10.0 & - \\
Skin empl. & $3.0 \times 10^{-15}$ & 0.21 & 0.21 & $1.0 \times 10^{-9}$ & 0.02 & - \\
2D model & & & & & & \\
Gap obs. & $3.0 \times 10^{-10}$ & 1.0 & 274.59 & $1.0 \times 10^{-5}$ & 10.0 & 10.0 \\
Gap ext. & $3.0 \times 10^{-10}$ & 1.0 & 122.40 & $1.0 \times 10^{-5}$ & 10.0 & 10.0 \\
Skin obs. & $3.0 \times 10^{-14}$ & 0.21 & 0.21 & $1.0 \times 10^{-9}$ & 0.10 & 0.05 \\
Skin ext. & $3.0 \times 10^{-13}$ & 0.21 & 0.21 & $1.0 \times 10^{-9}$ & 0.10 & 0.05 \\
Fault gouge & $3.0 \times 10^{-13}$ & 0.21 & 0.21 & $1.0 \times 10^{-9}$ & 0.10 & 0.05 \\
\hline
\end{tabular}

\subsection{Boundary conditions}

In order to simulate the varying flow regime we used the flow rates displayed in Figure 2. Flow rates used in the numerical models were based on the monitored data. The 1D model assumed a time dependent injection flow rate of the Grimsel groundwater at the gap of the emplacement borehole. During the initial diffusion period (August 2009 to October 2010), 
when there was no injection, the concentration at the skin-fracture interface (the last node of the 1D model) was fixed at that of the Grimsel groundwater. After the diffusion period, when water was injected into the gap, the 1D model assumed an outflowing mass flux boundary condition at the skin-fracture interface (mass flux equals flow rate times concentration at the boundary). The 2D model started after the initial diffusion period (October 2010). The 2D model considered the time depending flow rates at the three boreholes, shown in Figure 2. At the observation and extraction boreholes there was only extraction. The solute concentrations of the outflowing water of the 1D model were used for the inflowing water entering the $2 \mathrm{D}$ model (at the skin-fracture interface of the emplacement borehole). At the observation and extraction boreholes the $2 \mathrm{D}$ model assumed an outflowing mass flux boundary condition.

a) Emplacement

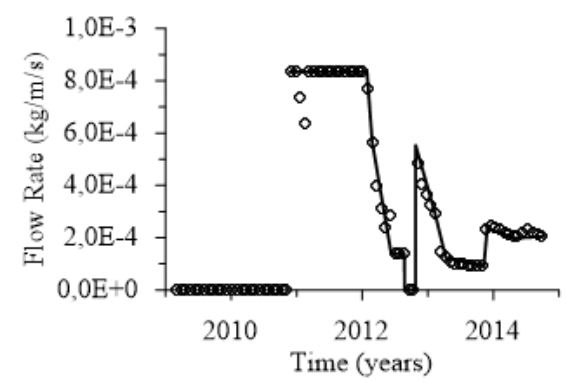

b) Observation
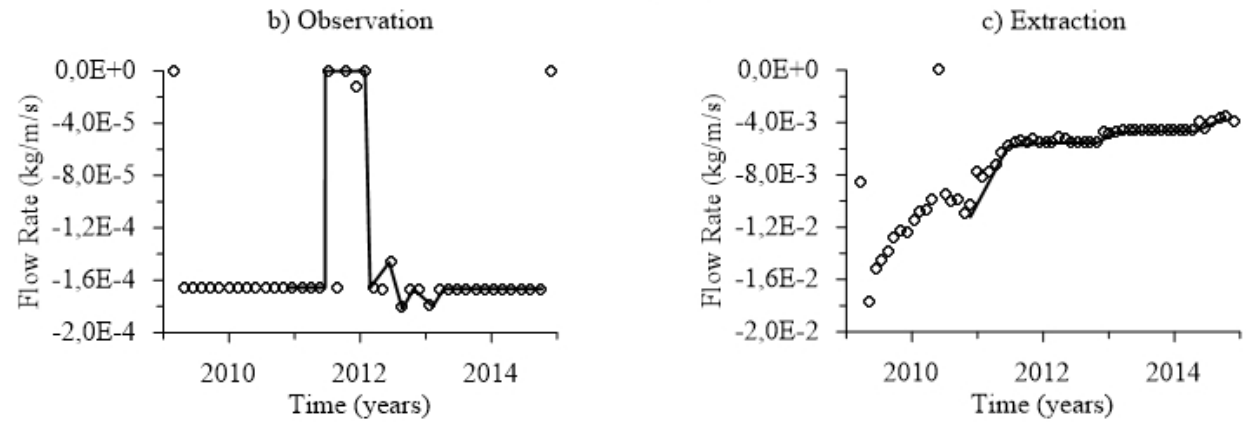

Figure 2: Boundary conditions. Flow rate for the emplacement, observation and extraction boreholes. Points are the measured data and lines the model flow rates. The 1D model started on August 2009 and the 2D model started on October 2010. 


\subsection{Chemical System}

\subsubsection{Cement and rock composition}

Table 2 gives the initial composition of the cement paste in the emplacement borehole considered by the numerical model. The cement composition was based on the results of a calculation using the GEM-Selektor (GEMS) software package (Wagner et al., 2012; Kulik et al., 2013) which can handle equilibrium phase assemblage and speciation in a complex chemical system from its total bulk elemental composition. In the numerical model Fe was not considered to simplify the chemical system. The primary phases that were taken into account are $\mathrm{C}-\mathrm{S}-\mathrm{H}$ gel $(\mathrm{Ca} / \mathrm{Si}=1.667)$, portlandite, ettringite, siliceous hydrogarnet and hydrotalcite. C-S-H gel was modelled as 5 pure solid phases with $\mathrm{Ca} / \mathrm{Si}$ ratios ranging from 0.83 to 1.67 (Trapote-Barreira et al., 2014). C-S-H gel with a Ca/Si of 1.667 was the primary phase and the others were secondary phases. The potential secondary phases considered were C-A-S-H, tobermorite, calcite, monosulfoaluminate, monocarboaluminate, illite and M-S-H. C-A-S-H is also a solid solution, but in this case only 3 phases were considered with a $\mathrm{Ca} / \mathrm{Si}$ ratio of 1 and $\mathrm{Al} / \mathrm{Si}$ ratios equal to 0.05, 0.10 and 0.15 (Myers et al., 2015). M-S-H, another solid solution, was also considered. We only used the end-member compositions $\left(\mathrm{M}_{3} \mathrm{~S}_{4} \mathrm{H}_{5}\right.$ and $\mathrm{M}_{3} \mathrm{~S}_{2} \mathrm{H}_{5}$ ) with $\mathrm{Mg} / \mathrm{Si}$ ratios of 0.7 and 1.5 (Nied et al., 2016). The sensitivity case including zeolites and additional crystalline C-S-H phases were also considered as secondary phases, which are laumontite, analcime, natrolite, mordenite, wairakite, foshagite, gyrolite and okenite. Table 3 shows the initial composition of the fault gouge. The minerals considered were quartz, K-feldspar, albite, muscovite and phlogopite. The volumetric fractions of the minerals, the porosity and the surface areas were from Soler and Mäder (2010).

\subsubsection{Solution composition}

Table 4 shows the initial compositions of the cement porewater and the Grimsel groundwater (the initial groundwater in the fault gouge). The temperature of both waters was $15^{\circ} \mathrm{C}$. The initial composition of the cement porewater is at equilibrium with the cement phases. The initial composition

of the Grimsel groundwater was at equilibrium with the minerals of the fault gouge and was also based on the monitored data. 
Table 2: Cement composition.

\begin{tabular}{lll}
\hline Mineral & $\begin{array}{l}\text { Vol. frac. } \\
\left(\mathrm{m}^{3} \mathrm{~m}^{-3}\right)\end{array}$ & $\begin{array}{l}\sigma_{m} \\
\left(\mathrm{~m}^{2} \mathrm{~m}^{-3}\right)\end{array}$ \\
\hline C-S-H-1667 & 0.275 & $1.0 \times 10^{6}$ \\
Portlandite & 0.126 & $1.0 \times 10^{9}$ \\
Ettringite & $4.66 \times 10^{-2}$ & $1.0 \times 10^{6}$ \\
Hydrogarnet & $6.70 \times 10^{-2}$ & $1.0 \times 10^{6}$ \\
Hydrotalcite & $9.66 \times 10^{-3}$ & $1.0 \times 10^{6}$ \\
Porosity & 0.476 & \\
\hline
\end{tabular}

Table 3: Fault gouge (unconsolidated granite) composition, based on Soler and Mäder (2010).

\begin{tabular}{lll}
\hline Mineral & $\begin{array}{l}\text { Vol. frac. } \\
\left(\mathrm{m}^{3} \mathrm{~m}^{-3}\right)\end{array}$ & $\begin{array}{l}\sigma_{m} \\
\left(\mathrm{~m}^{2} \mathrm{~m}^{-3}\right)\end{array}$ \\
\hline Quartz & 0.19 & $1.07 \times 10^{4}$ \\
K-feldspar & 0.15 & $8.48 \times 10^{3}$ \\
Albite & 0.14 & $7.92 \times 10^{3}$ \\
Muscovite & 0.22 & $1.24 \times 10^{4}$ \\
Phlogopite & 0.09 & $5.1 \times 10^{3}$ \\
Porosity & 0.21 & \\
\hline
\end{tabular}


Table 4: Initial composition of the cement porewater and composition of the Grimsel groundwater water. Imposed constraints to calculate some of these values (equilibrium with solids or charge balance) are also indicated.

\begin{tabular}{|c|c|c|c|}
\hline Component & $\begin{array}{l}\text { Cement pore water } \\
\left(\mathrm{mol} \mathrm{L}^{-1}\right)\end{array}$ & $\begin{array}{l}\text { Grimsel gr } \\
\left(\mathrm{mol} \mathrm{L}^{-1}\right)\end{array}$ & undwater \\
\hline $\mathrm{Ca}^{2+}$ & $5.20 \times 10^{-3} \quad$ Portlandite & $1.10 \times 10^{-4}$ & Calcite \\
\hline $\mathrm{HSiO}_{3}^{-}$ & $6.49 \times 10^{-5} \quad$ C-S-H-1667 & $8.31 \times 10^{-5}$ & Quartz \\
\hline $\mathrm{Al}(\mathrm{OH})_{4}^{-}$ & $2.04 \times 10^{-5} \quad$ Hydrogarnet & $1.24 \times 10^{-7}$ & Muscovite \\
\hline $\mathrm{K}^{+}$ & $8.91 \times 10^{-2}$ & $1.72 \times 10^{-5}$ & K-feldspar \\
\hline $\mathrm{Na}^{+}$ & $9.95 \times 10^{-3}$ & $5.22 \times 10^{-4}$ & \\
\hline $\mathrm{SO}_{4}^{2-}$ & $3.98 \times 10^{-5} \quad$ Ettringite & $5.20 \times 10^{-5}$ & \\
\hline $\mathrm{Mg}^{2+}$ & $1.5 \times 10^{-9} \quad$ Hydrotalcite & $8.48 \times 10^{-7}$ & Phlogopite \\
\hline $\mathrm{Cl}^{-}$ & $1.0 \times 10^{-15}$ & $7.62 \times 10^{-5}$ & \\
\hline $\mathrm{F}^{-}$ & $1.0 \times 10^{-15}$ & $1.63 \times 10^{-4}$ & \\
\hline $\mathrm{CO}_{3}^{2-}$ & $4.98 \times 10^{-7}$ & $3.17 \times 10^{-4}$ & charge bal. \\
\hline $\mathrm{pH}$ & 13.23 charge bal. & 9.65 & \\
\hline
\end{tabular}




\subsubsection{Thermodynamic data}

The thermodynamic data $\left(\right.$ at $\left.15^{\circ} \mathrm{C}\right)$ for all the mineral reactions are given in Tables 5 and 6 . The equilibrium constants $(\log \mathrm{K})$ for quartz, K-feldspar, albite, muscovite, phlogopite, tobermorite, illite, calcite, all the zeolites and C-S-H crystalline phases were taken from EQ3/6 database (Wolery et al., 1990); C-S-H gel phases from Kulik and Kersten (2001); portlandite, ettringite, hydrogarnet, hydrotalcite, monocarboaluminate and monosulfoaluminate from the cemdata07 database (Matschei et al., 2007), C-A-S-H phases from Myers et al. (2015) and M-S-H phases from Nied et al. (2016). Table 7 shows the equilibrium constants (log $\mathrm{K}$ ) for aqueous complexation reactions which were taken from EQ3/6 database (Wolery et al., 1990).

Table 5: Equilibrium constants of primary minerals taken into account in the numerical model $\left(\log \mathrm{K}\right.$ at $\left.15^{\circ} \mathrm{C}\right)$. Reactions were written as the dissolution of $1 \mathrm{~mol}$ of mineral in terms of the primary species $\mathrm{Ca}^{2+}, \mathrm{HSiO}_{3}^{-}, \mathrm{Al}(\mathrm{OH})_{4}^{-}, \mathrm{OH}^{-}, \mathrm{SO}_{4}^{2-}, \mathrm{Mg}^{2+}, \mathrm{CO}_{3}^{2-}, \mathrm{K}^{+}$, $\mathrm{Na}^{+}, \mathrm{Cl}^{-}$and $\mathrm{F}^{-}$. a) EQ3/6 database (Wolery et al., 1990), b) Kulik and Kersten (2001) c) cemdata07 database Matschei et al. (2007)

\begin{tabular}{|c|c|c|}
\hline Mineral & Formula & $\log \mathrm{K}_{e q}$ \\
\hline Quartz & $\mathrm{SiO}_{2}$ & $0.02^{\text {(a) }}$ \\
\hline K-feldspar & $\mathrm{KAlSi}_{3} \mathrm{O}_{8}$ & $-11.63^{(\mathrm{a})}$ \\
\hline Albite & $\mathrm{NaAlSi}_{3} \mathrm{O}_{8}$ & $-8.42^{(a)}$ \\
\hline Muscovite & $\mathrm{KAl}_{3} \mathrm{Si}_{3} \mathrm{O}_{10}(\mathrm{OH})_{2}$ & $-16.10^{(a)}$ \\
\hline Phlogopite & $\mathrm{KMg}_{3}\left(\mathrm{AlSi}_{3} \mathrm{O}_{10}\right)(\mathrm{OH})_{2}$ & -58.20 \\
\hline C-S-H-1667 & $\mathrm{SiO}_{2} \cdot 1.67 \mathrm{Ca}(\mathrm{OH})_{2} \cdot 1 \mathrm{H}_{2} \mathrm{O}$ & $-13.47^{(b)}$ \\
\hline Portlandite & $\mathrm{Ca}(\mathrm{OH})_{2}$ & $-5.07^{(\mathrm{c})}$ \\
\hline Ettringite & $\mathrm{Ca}_{6} \mathrm{Al}_{2}\left(\mathrm{SO}_{4}\right)_{3}(\mathrm{OH})_{12} \cdot 26 \mathrm{H}_{2} \mathrm{O}$ & $-46.10^{(\mathrm{c})}$ \\
\hline Hydrogarnet & $3 \mathrm{CaO} \cdot \mathrm{Al}_{2} \mathrm{O}_{3} \cdot 0.84 \mathrm{SiO}_{2} \cdot 4.32 \mathrm{H}_{2} \mathrm{O}$ & $-26.82^{(\mathrm{c})}$ \\
\hline Hydrotalcite & $\mathrm{Mg}_{4} \mathrm{Al}_{2}(\mathrm{OH})_{14} \cdot 3 \mathrm{H}_{2} \mathrm{O}$ & $-56.66^{(\mathrm{c})}$ \\
\hline
\end{tabular}

\subsubsection{Reaction rates}

A kinetic approach was used for the dissolution-precipitation of mineral phases (Eq. 1), although sometimes the reaction is fast enough to be at local 
Table 6: Equilibrium constants of secondary minerals taken into account in the numerical model $\left(\log \mathrm{K}\right.$ at $\left.15^{\circ} \mathrm{C}\right)$. Reactions were written as the dissolution of $1 \mathrm{~mol}$ of mineral in terms of the primary species $\mathrm{Ca}^{2+}, \mathrm{HSiO}_{3}^{-}, \mathrm{Al}(\mathrm{OH})_{4}^{-}, \mathrm{OH}^{-}, \mathrm{SO}_{4}^{2-}, \mathrm{Mg}^{2+}, \mathrm{CO}_{3}^{2-}, \mathrm{K}^{+}$, $\mathrm{Na}^{+}, \mathrm{Cl}^{-}$and $\mathrm{F}^{-}$. a) EQ3/6 database (Wolery et al., 1990), b) Kulik and Kersten (2001) c) cemdata07 database Matschei et al. (2007) d) Myers et al. (2015) e) Nied et al. (2016).

\begin{tabular}{|c|c|c|}
\hline Mineral & Formula & $\log \mathrm{K}_{e q}$ \\
\hline C-S-H-083 & $2.27 \mathrm{SiO}_{2} \cdot 1.82 \mathrm{Ca}(\mathrm{OH})_{2} \cdot 1.82 \mathrm{H}_{2} \mathrm{O}$ & $-17.12^{(b)}$ \\
\hline C-S-H-10 & $\mathrm{SiO}_{2} \cdot \mathrm{Ca}(\mathrm{OH})_{2} \cdot 0.86 \mathrm{H}_{2} \mathrm{O}$ & $-9.35^{(b)}$ \\
\hline C-S-H-12 & $\mathrm{SiO}_{2} \cdot 1.2 \mathrm{Ca}(\mathrm{OH})_{2} \cdot 0.91 \mathrm{H}_{2} \mathrm{O}$ & $-10.70^{(b)}$ \\
\hline C-S-H-14 & $\mathrm{SiO}_{2} \cdot 1.4 \mathrm{Ca}(\mathrm{OH})_{2} \cdot 0.95 \mathrm{H}_{2} \mathrm{O}$ & $-11.95^{(b)}$ \\
\hline C-A-S-H-05 & $(\mathrm{CaO})_{1}\left(\mathrm{Al}_{2} \mathrm{O}_{3}\right)_{0.025}\left(\mathrm{SiO}_{2}\right)_{1}\left(\mathrm{H}_{2} \mathrm{O}\right)_{1.2}$ & $-10.28^{(d)}$ \\
\hline C-A-S-H-10 & $(\mathrm{CaO})_{1}\left(\mathrm{Al}_{2} \mathrm{O}_{3}\right)_{0.05}\left(\mathrm{SiO}_{2}\right)_{1}\left(\mathrm{H}_{2} \mathrm{O}\right)_{1.2}$ & $-10.21^{(d)}$ \\
\hline C-A-S-H-15 & $(\mathrm{CaO})_{1}\left(\mathrm{Al}_{2} \mathrm{O}_{3}\right)_{0.075}\left(\mathrm{SiO}_{2}\right)_{1}\left(\mathrm{H}_{2} \mathrm{O}\right)_{1.2}$ & $-10.02^{(d)}$ \\
\hline Monocarb. & $\mathrm{Ca}_{4} \mathrm{Al}_{2}\left(\mathrm{CO}_{3}\right)(\mathrm{OH})_{12} \cdot 5 \mathrm{H}_{2} \mathrm{O}$ & $-31.85^{(\mathrm{c})}$ \\
\hline Monosulf. & $\mathrm{Ca}_{4} \mathrm{Al}_{2}\left(\mathrm{SO}_{4}\right)(\mathrm{OH})_{12} \cdot 6 \mathrm{H}_{2} \mathrm{O}$ & $-29.50^{(\mathrm{c})}$ \\
\hline Tobermorite & $\mathrm{Ca}_{5} \mathrm{Si}_{6} \mathrm{H}_{21} \mathrm{O}_{27.5}$ & $-52.77^{(a)}$ \\
\hline Illite & $\mathrm{Mg}_{0.25} \mathrm{~K}_{0.6} \mathrm{Al}_{2.3} \mathrm{Si}_{3.5} \mathrm{O}_{10}(\mathrm{OH})_{2}$ & $-13.53^{(a)}$ \\
\hline Calcite & $\mathrm{CaCO}_{3}$ & $-8.41^{(a)}$ \\
\hline M-S-H-0.7 & $3 \mathrm{MgO} \cdot 4 \mathrm{SiO}_{2} \cdot 5 \mathrm{H}_{2} \mathrm{O}$ & $-40.61^{(e)}$ \\
\hline M-S-H-1.5 & $3 \mathrm{MgO} \cdot 2 \mathrm{SiO}_{2} \cdot 5 \mathrm{H}_{2} \mathrm{O}$ & $-38.60(\mathrm{e})$ \\
\hline Laumontite & $\mathrm{CaAl}_{2} \mathrm{Si}_{4} \mathrm{O}_{12} \cdot 4 \mathrm{H}_{2} \mathrm{O}$ & $-16.65^{(a)}$ \\
\hline Analcime & $\mathrm{Na}_{0.96} \mathrm{Al}_{0.96} \mathrm{Si}_{2.04} \mathrm{O}_{6} \cdot \mathrm{H}_{2} \mathrm{O}$ & -7.98 (a) \\
\hline Natrolite & $\mathrm{Na}_{2} \mathrm{Al}_{2} \mathrm{Si}_{3} \mathrm{O}_{10} \cdot 2 \mathrm{H}_{2} \mathrm{O}$ & $-16.00^{(a)}$ \\
\hline Mordenite & $\mathrm{Ca}_{0.28} \mathrm{Na}_{0.36} \mathrm{Al}_{0.94} \mathrm{Si}_{5.06} \mathrm{O}_{12} \cdot 3.46 \mathrm{H}_{2} \mathrm{O}$ & $-6.66^{(a)}$ \\
\hline Wairakite & $\mathrm{CaAl}_{2} \mathrm{Si}_{4} \mathrm{O}_{10}(\mathrm{OH})_{4}$ & $-11.92^{(a)}$ \\
\hline Foshagite & $\mathrm{Ca}_{4} \mathrm{Si}_{3} \mathrm{O}_{9}(\mathrm{OH})_{2} \cdot 0.5 \mathrm{H}_{2} \mathrm{O}$ & $-33.92^{(a)}$ \\
\hline Gyrolite & $\mathrm{Ca}_{2} \mathrm{Si}_{3} \mathrm{O}_{7}(\mathrm{OH})_{2} \cdot 1.5 \mathrm{H}_{2} \mathrm{O}$ & $-21.26^{(a)}$ \\
\hline Okenite & $\mathrm{CaSi}_{2} \mathrm{O}_{4}(\mathrm{OH})_{2} \cdot \mathrm{H}_{2} \mathrm{O}$ & $-9.71^{(\mathrm{a})}$ \\
\hline
\end{tabular}




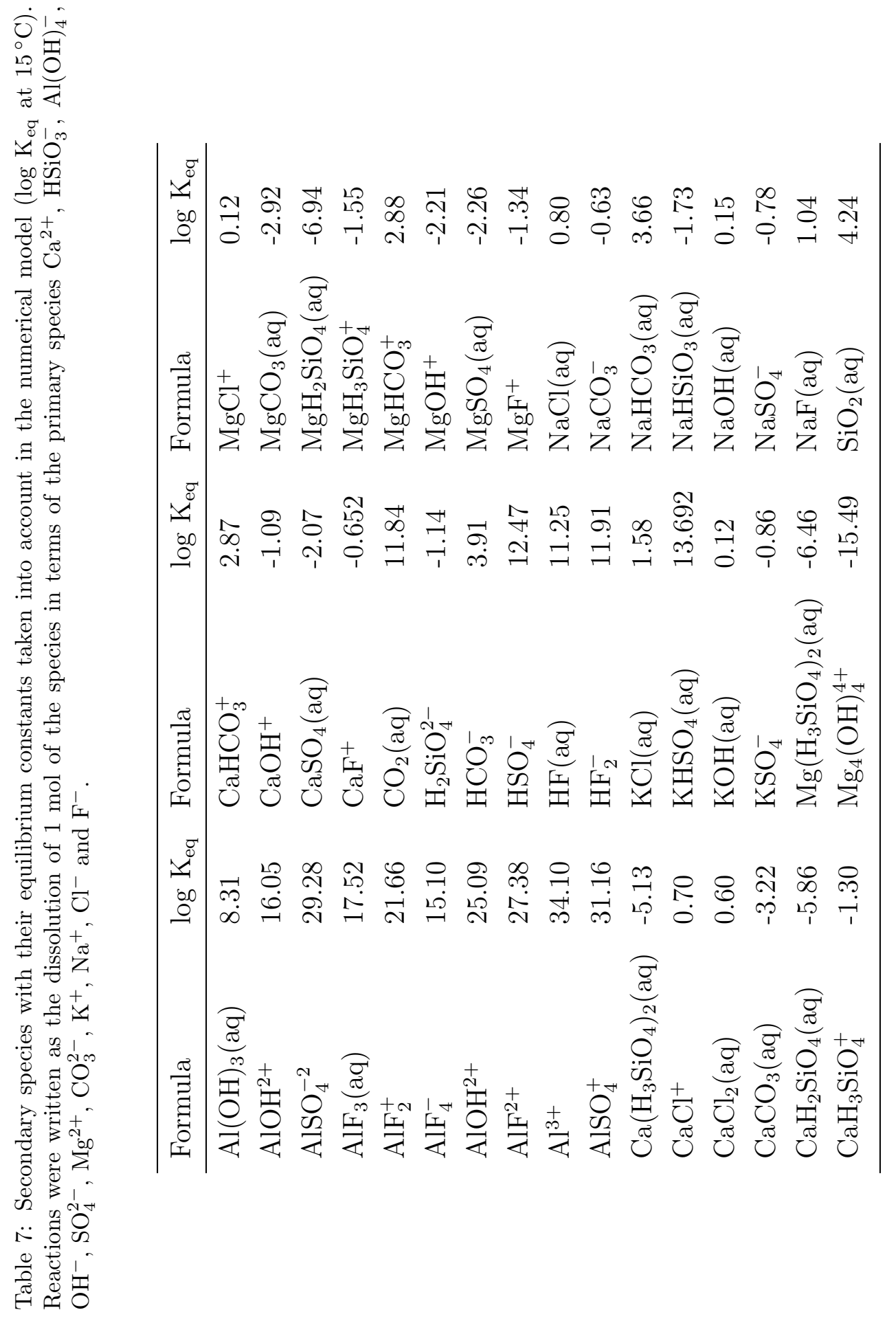


equilibrium. The rate laws used for the primary minerals in the fault gouge (quartz, albite, K-feldspar, phlogopite, muscovite), based on those used by Soler and Mäder (2010), are given in Equation 1 and Table 8.

$$
r_{\mathrm{m}}=k_{\mathrm{m}} \sigma_{\mathrm{m}}\left(\Omega_{\mathrm{m}}^{\theta}-1\right)^{\eta} a_{\mathrm{H}^{+}}^{\mathrm{pm}^{+}} \quad m=1, \ldots, n_{p}
$$

$r_{\mathrm{m}}$ is the mineral dissolution-precipitation rate $\left(\mathrm{mol} \mathrm{m}^{-2} \mathrm{~s}^{-1}\right), k_{\mathrm{m}}$ is the kinetic rate constant $\left(\mathrm{mol} \mathrm{m}{ }^{-2} \mathrm{~s}^{-1}\right), \sigma_{\mathrm{m}}$ is the surface area $\left(\mathrm{m}^{2} \mathrm{~m}^{-3}\right), a_{\mathrm{H}^{+}}$is the activity of protons, $p$ is a catalyzer coefficient, $\Omega_{\mathrm{m}}$ is $\frac{I A P}{K}$ where $I A P$ is the ionic activity product and $K$ is the equilibrium constant (ionic activity product at equilibrium).

The form of the rate law is from Lasaga (1984). Values of $\theta$ and $\eta$ for albite and microcline are from Soler and Lasaga (1998). For all the other phases (cement and secondary phases), large values of the rate constants $\left(1 \cdot 10^{-9} \mathrm{~mol} \mathrm{~m}^{-2} \mathrm{~s}^{-1}\right)$ and of the surface areas $\left(1 \cdot 10^{6} \mathrm{~m}^{2} \mathrm{~m}^{-3}\right)$ were used, leading to local equilibrium with respect to those phases. Initially, the gap had no minerals but large surface areas $\left(1 \cdot 10^{6} \mathrm{~m}^{2} \mathrm{~m}^{-3}\right)$ were implemented to allow mineral precipitation.

Table 8: Rate parameters used for the primary minerals in the fault gouge.

\begin{tabular}{lllll}
\hline Mineral & $\begin{array}{l}\log k_{\mathrm{m}} \\
\left(\mathrm{mol} \mathrm{m}^{-2} \mathrm{~s}^{-1}\right)\end{array}$ & $p_{\mathrm{m}}$ & $\theta$ & $\eta$ \\
\hline Quartz & -13.92 & -0.2 & 1.0 & 1.0 \\
K-feldspar & -20.22 & -0.73 & 0.4 & 14 \\
Albite & -12.92 & -0.2 & 0.4 & 14 \\
Muscovite & -13.12 & -0.1 & 1.0 & 1.0 \\
Phlogopite & -13.52 & -0.2 & 1.0 & 1.0 \\
\hline
\end{tabular}

\section{Results and Discussion}

Before discussing the results of the model, we first calculated some characteristic times on which transport processes took place. This is helpful for the interpretation of the results of the models. Then we will discuss the 
results of the $1 \mathrm{D}$ radial model for the domain in the vicinity of the emplacement borehole, followed by the results of the 2D model for the domain with three boreholes: emplacement, observation and extraction.

\subsection{Characteristic times}

A characteristic time for diffusion, $t_{\text {dif }}$, is defined as:

$$
t_{\mathrm{dif}}=\frac{\left(L_{2}-L_{1}\right)^{2}}{D_{\mathrm{p}}}
$$

where $D_{\mathrm{p}}$ is the pore diffusion coefficient and $L_{1}$ and $L_{2}$ are the two boundaries between which diffusion takes place. This means that when there are no changes at the boundaries, a steady state is reached after a time of roughly $t_{\text {dif }}$. Equation 2 only makes sense when diffusion is the dominant process, that is, only in the cement and in the skin of the emplacement borehole, the last only during the initial diffusion period. A characteristic time for advection, $t_{\mathrm{adv}}$, can be defined in a radial system as:

$$
t_{\mathrm{adv}}=\frac{\pi \phi b\left(L_{2}^{2}-L_{1}^{2}\right)}{Q}
$$

where $\phi, b$ and $Q$ are porosity, thickness of the system and injection or extraction flow rate, respectively. This means $t_{\mathrm{adv}}$ is the time it takes water and a dissolved solute to flow from $L_{1}$ to $L_{2}$.

A third characteristic time is the average transient time of a solute in an ideally mixed system, $t_{\text {mix }}$.

$$
t_{\text {mix }}=\frac{V}{Q}
$$

where $V$ is the volume of the ideally mixed system. The model volume includes the gap between the dummy cylinder or cement and the borehole wall plus the volume of water circulating in tubes and reservoir tank.

Table 9 shows the calculated characteristic times for the various processes. It can be seen that diffusion is the slowest transport process and, therefore, may be the one that controls the system the most. Advection times are short, indicating that water probably will not change its chemistry very much due to precipitation/dissolution of minerals during its passage through the fracture and skins as there is not much time for reactions to occur. 
Table 9: Characteristic times for the different processes. Characteristic times for diffusion, advection and ideal mixing were calculated by equations 2,3 and 4, respectively. Characteristic times with two values were calculated from minimum and maximum flow rates.

\begin{tabular}{lll}
\hline Process & Location & $\mathrm{t}_{c}(\mathrm{~d})$ \\
\hline $\begin{array}{l}\text { Diffusion } \\
\left(t_{\text {dif }}\right)\end{array}$ & Cement & 14.7 \\
Advection & Skin of the emplacement borehole & 15.8 \\
$\left(t_{\text {adv }}\right)$ & Skin of the emplacement borehole & $0.0035-0.032$ \\
Ideal mixing & From emplacement to extraction borehole & $0.69-2.14$ \\
$\left(t_{\text {mix }}\right)$ & Gap of emplacement borehole & $13.6-124.6$ \\
& Gap of observation borehole & 14.9 \\
& Gap of extraction borehole & $0.07-0.21$ \\
\hline
\end{tabular}

\subsection{D Model}

Figure 3 shows the measured and modelled aqueous chemistry against time at the gap of the emplacement borehole. There are discrepancies between model results and the monitored data at the emplacement borehole. Generally, the measured data are more scattered then the model results. A possible explanation is the assumption of ideally mixed water in gap, tank and tubing of the emplacement borehole. This assumption is particularly doubtful for the periods without water injection (before October 2010 and at the end of 2013, see Figure 2) during which coincidentally the majority of measurements were made. A smaller volume available for mixing would give less storage capacity leading to more pronounced changes in concentrations. Another explanation is that the flow around the emplacement borehole may not be perfectly radial as assumed by the model. However, we can compare qualitatively the measured data with the model results in order to understand the reactions that have occurred during the experiment. The model shows that at the beginning there was a rapid increase of $\mathrm{pH}, \mathrm{Ca}, \mathrm{K}$ and $\mathrm{Na}$ concentrations because of out-diffusion from the cement. Si decreased due to diffusion towards cement and $\mathrm{SO}_{4}$ decreased because of precipitation in rock (ettringite) plus diffusion from gap towards rock. $\mathrm{Cl}$ and $\mathrm{F}$ also decreased because cement pore water did not contain these components. From the beginning of the injection on, Ca concentration varied according to the changes in the flow rates. Higher injection rates implied lower Ca concentrations. K 
and $\mathrm{Na}$ concentrations decreased until there high concentrations disappeared from the cement pore water. Si concentration remained approximately constant, as this concentration was very similar to the Grimsel water and the cement pore water. Small variations can be seen in concentrations of $\mathrm{SO}_{4}$ and $\mathrm{Al} . \mathrm{Cl}$ and $\mathrm{F}$ concentration increased at the beginning of the injection period until they reached the same concentration as in Grimsel groundwater. $\mathrm{pH}$ varied according to the variations in Ca concentration.

Figure 4 displays the variation of volumetric fraction of minerals versus distance calculated by the munerical model. In the $x$ axis, cement (from 0.035 to $0.041 \mathrm{~m}$ ), gap (from 0.041 to $0.043 \mathrm{~m}$ ) and the skin (from 0.043 to 0.08 $\mathrm{m})$ are represented. These results can be compared with the postmortem analysis and the mineralogical analysis. In the cement, model results show dissolution of portlandite, with a sharp dissolution front at $3 \mathrm{~mm}$ from the cement-gap interface after 5 years. This dissolution of portlandite, which was also observed in the postmortem analysis, allowed the calibration of the pore diffusion coefficient with a value of $2 \cdot 10^{-11} \mathrm{~m}^{2} / \mathrm{s}$. Also C-S-H $(\mathrm{Ca} / \mathrm{Si}=1.6)$ dissolved though at a smaller rate. Ettringite dissolved at the interface between the cement and gap only after injection of water was started. On the other hand, after injecting Grimsel groundwater, C-A-S-H $(\mathrm{Al} / \mathrm{Si}=0.05$ and $\mathrm{Ca} / \mathrm{Si}=1$ ) precipitated near the gap and calcite did at the cement-gap interface and into the gap, due to the mixing of both waters. This calcite precipitation at the interface was also observed in the observations by EMPA (unpublished results). At the skin, during both diffusion and injection periods, the primary minerals of the fault gouge (quartz, albite, K-feldspar, muscovite and phlogopite) dissolved due to the high-pH conditions. Also, there was precipitation at the skin of C-A-S-H, ettringite and hydrotalcite. One can also observe precipitation of smaller amounts of calcite, hydrogarnet and monocarboaluminate. Precipitation of C-A-S-H and calcite is consistent with mineralogical analysis of the overcore performed by the BGS (unpublished results). However, ettringite was not observed. Traces of gypsum were detected in scrapings from the borehole wall.

The variation of porosity due to precipitation and dissolution of minerals is shown in Figure 5. The porosity change in the cement paste is mainly due to portlandite dissolution. It increased by 0.12 corresponding to the initial volume fraction of portlandite in the cement. The porosity reduced slightly in the skin next to the gap due to C-A-S-H, ettringite and hydrotalcite precipitation. 

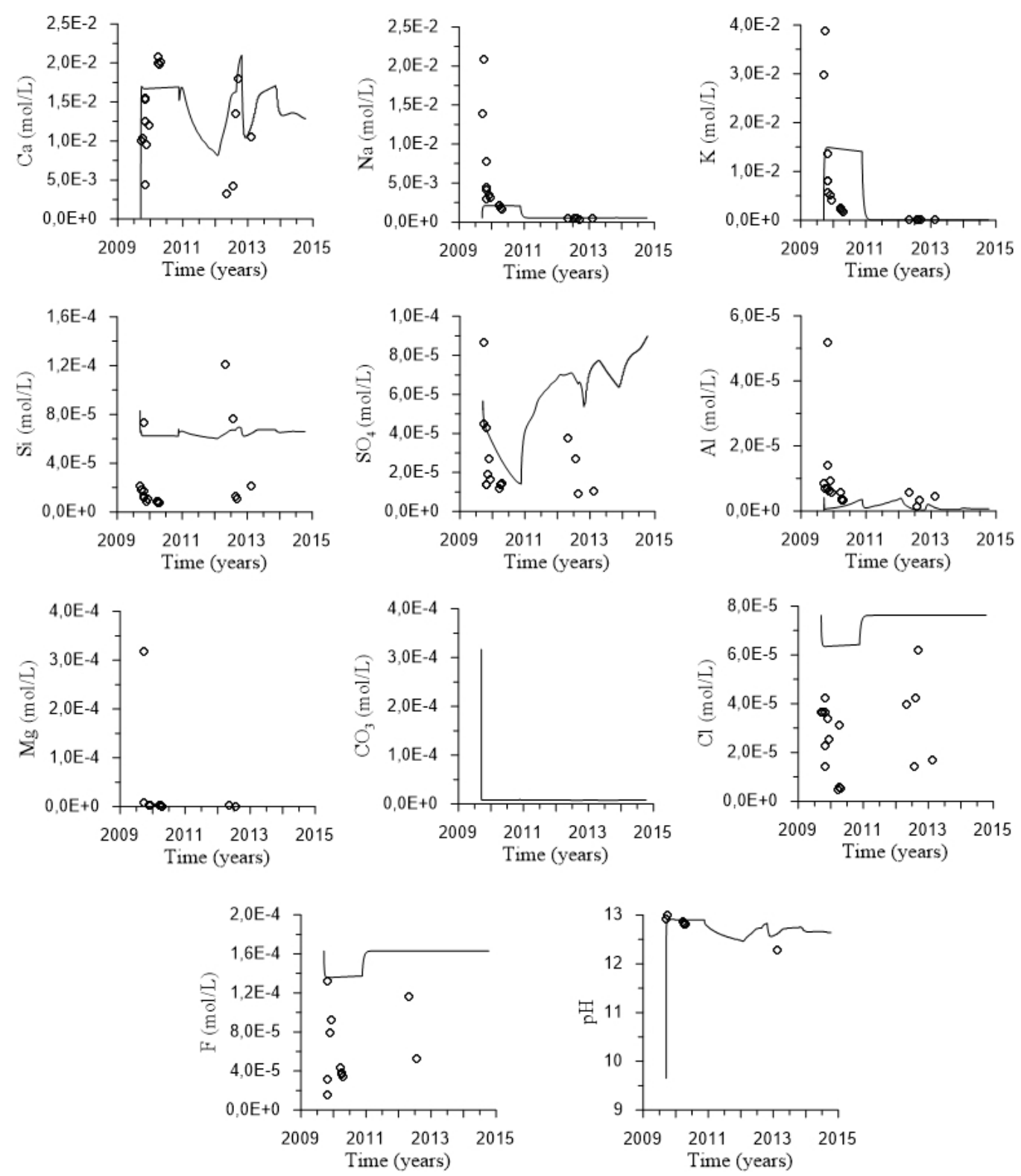

Figure 3: Evolution of the measured concentrations (points) compared with the ones calculated by the numerical model (lines). 

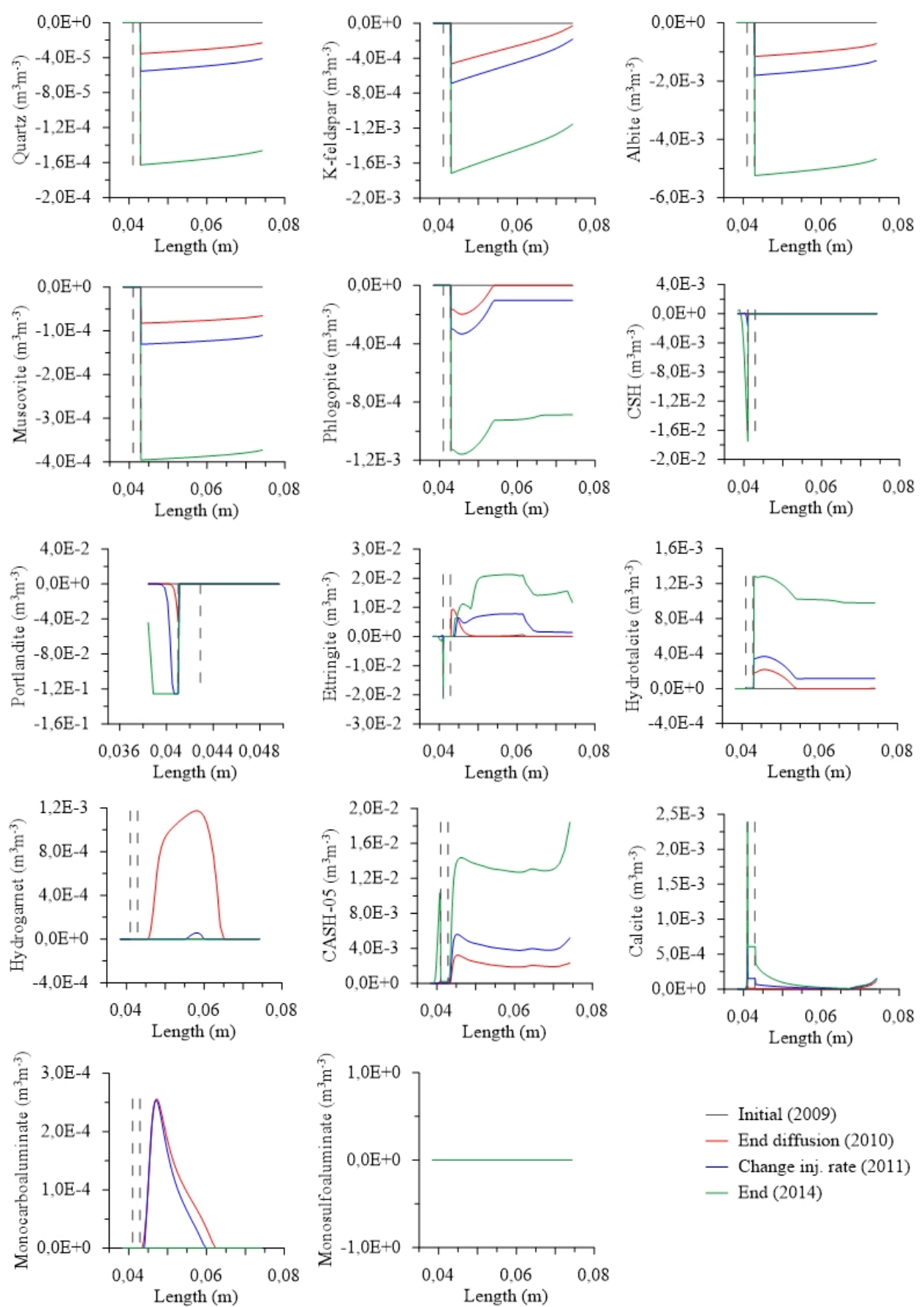

Figure 4: Variation of volumetric fraction of minerals against length. Positive values mean precipitation and negative ones mean dissolution. Vertical dashed lines indicate the gap. 


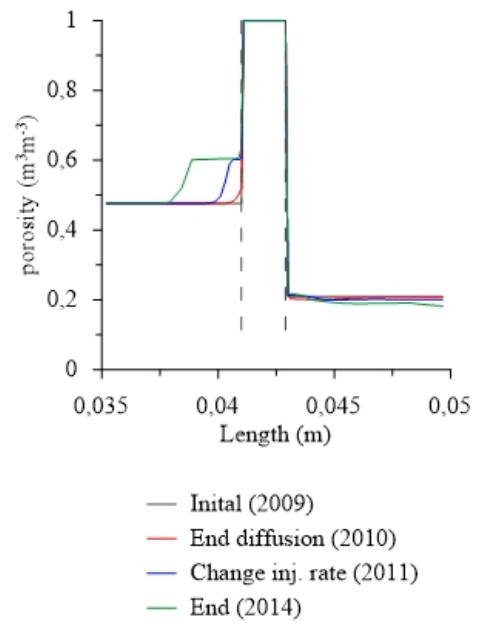

Figure 5: Variation of porosity against length. Vertical dashed lines indicate the position of the gap between cement and fracture.

\subsection{D Model}

Before discussing the results of the $2 \mathrm{D}$ reactive transport model, we will first look at conservative transport. This can be characterized by a mixing ratio, $\lambda$, between the background Grimsel water and water injected at the emplacement borehole reacted with the cement paste. Its value can be calculated from the concentrations of a conservative tracer with Equation 5,

$$
\lambda=\frac{c-c_{g r i}}{c_{e m p}-c_{g r i}}
$$

where subscripts gri and emp represent Grimsel groundwater and emplacement water, respectively. A $\lambda$ of 0 means pure Grimsel groundwater and a $\lambda$ of 1 means pure emplacement water reacted with cement.

The distribution of the mixing ratio in Figure 6 shows that the mixing ratio in the observation borehole was much larger than in the extraction borehole, the second being the furthest away from the emplacement borehole. Also, with higher injection rates at the emplacement borehole (October 2010) the size of the plume was larger than for lower injection rates (September 2014).

Figure 7 displays the modelled and measured aqueous chemistry versus time. The oscillations of the modelled chemistry are due to the changing flow rates. These oscillations can also be observed for the measured chemistry. 


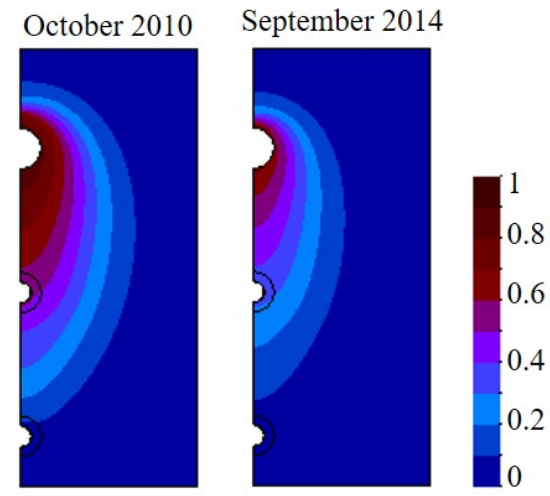

Figure 6: Mixing ratio distribution at two instants for the 2D model. A $\lambda$ of 0 means pure Grimsel groundwater and a $\lambda$ of 1 means pure emplacement water reacted with cement paste.

As for the emplacement borehole, the observed data are more scattered then the modelled results. Moreover, the model seems to overestimate the effect of the alkaline plume at the observation borehole. Part of this may be due to simplifications in the 1D model; its results were used as input for the 2D model. In addition, heterogeneity in both permeability and distribution of minerals can have an effect, which was not taken into account by the model (an initially homogeneous fracture was assumed). Bearing these limitations in mind, reasonable fits were obtained for both observation and extraction boreholes. However, modelled Si concentrations are lower than the measured ones. This is because the initial composition of Grimsel groundwater assumes equilibrium with quartz.

The calculated variation of the volume fractions of minerals of the fault gouge are displayed in Figure 8. All the minerals of the fault gouge (quartz, albite, K-feldspar, muscovite and phlogopite) were affeted by dissolution in the centre of the plume, due to the increase in $\mathrm{pH}$. Albite was dissolving in larger amounts followed by K-feldspar and phlogopite. There was less dissolution of quartz and muscovite. Notice that the hyperalcaline plume has a concentric shape due the fact that our model considered a homogeneous fracture. In reality the shape of the plume will depend on heterogeneities and preferential flow paths in the fracture.

Precipitation and dissolution of secondary minerals are shown in Figure 9. Ettringite precipitated at the edge of the emplacement borehole skin. C$\mathrm{A}-\mathrm{S}-\mathrm{H}(\mathrm{Al} / \mathrm{Si}=0.05$ and $\mathrm{Ca} / \mathrm{Si}=1)$ precipitated in the centre of the plume 

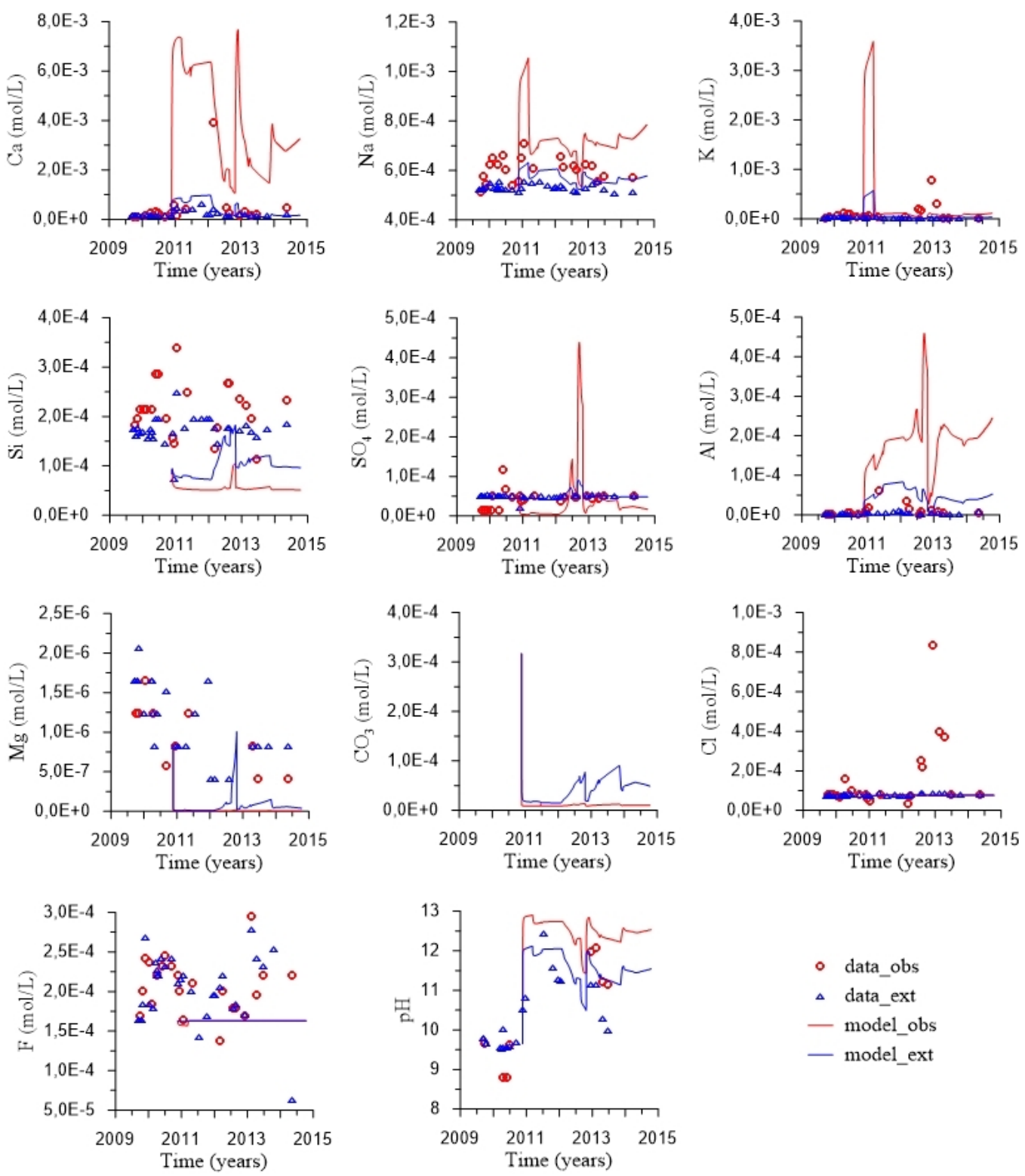

Figure 7: Modelled (lines) and measured (points) total aqueous concentrations and $\mathrm{pH}$ versus time for the observation and extraction boreholes. 

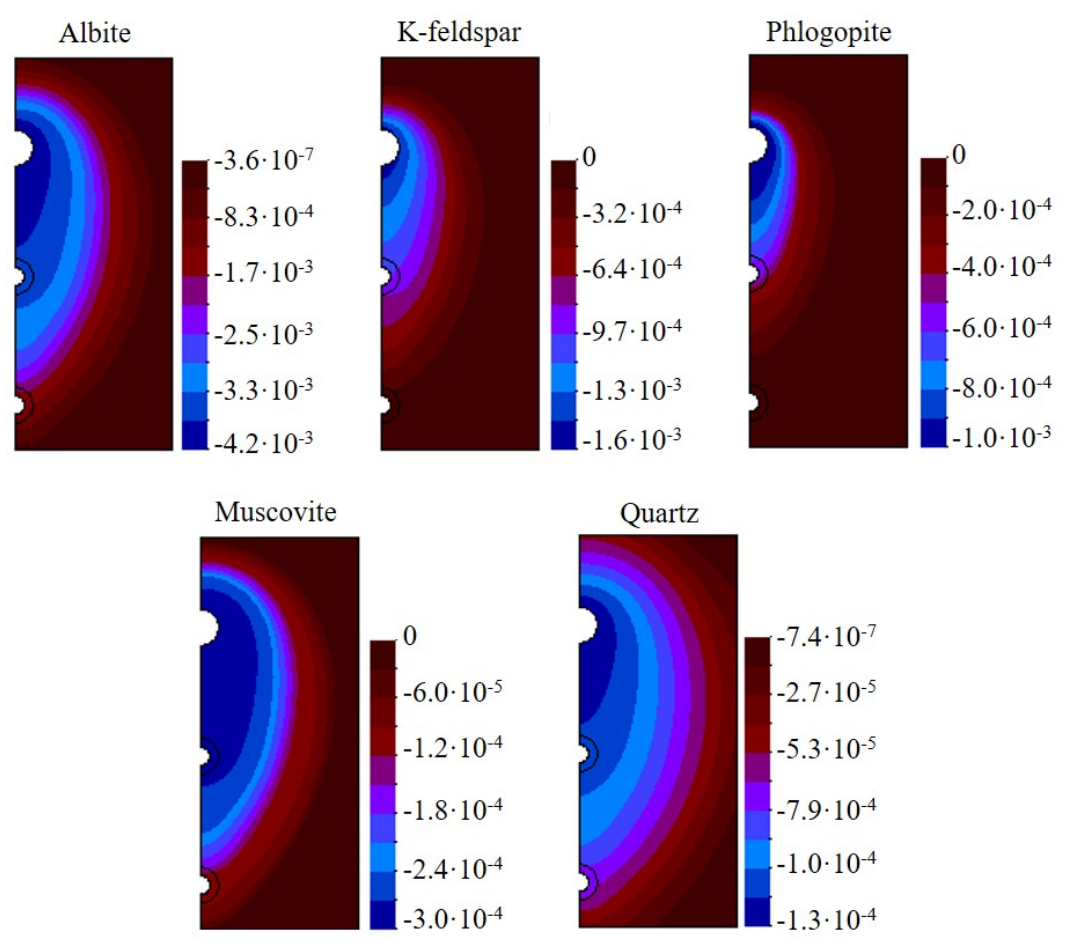

Figure 8: Variation of volumetric fraction $\left(\mathrm{m}^{3} \mathrm{~m}^{3}\right)$ of primary minerals of the rock at the end of the experiment. Negative values mean dissolution. Dimensions are $1.7 \mathrm{~m}$ x $0.7 \mathrm{~m}$. 
followed by the precipitation of tobermorite. Hydrotalcite precipitated at the centre of the plume and near the extraction borehole. Small amounts of monocarboaluminate and hydrogarnet also precipitated at the centre of the plume. Near the extraction borehole there was a lot of precipitation of calcite and to a lesser extent also of illite. This precipitation of calcite is because of the high extraction flow rate near that borehole, causing a lot of mixing between the alkaline water and Grimsel groundwater. Figure 9 also displays the distribution of porosity and $\mathrm{pH}$. Near the emplacement borehole there was a reduction in porosity of 0.02 due to ettringite precipitation. In the centre of the plume there is a similar reduction due to $\mathrm{C}-\mathrm{A}-\mathrm{S}-\mathrm{H}$ ( $\mathrm{Al} / \mathrm{Si}=0.05$ and $\mathrm{Ca} / \mathrm{Si}=1$ ) and hydrotalcite precipitation. Near the extraction borehole there is high reduction in porosity of 0.09 , because illite and especially calcite precipitated at the outer edge of the plume. The $\mathrm{pH}$ plot shows the distribution of the alkaline plume, with higher $\mathrm{pH}$ close to the emplacement borehole because of the cement source and lower $\mathrm{pH}$ near the extraction borehole.
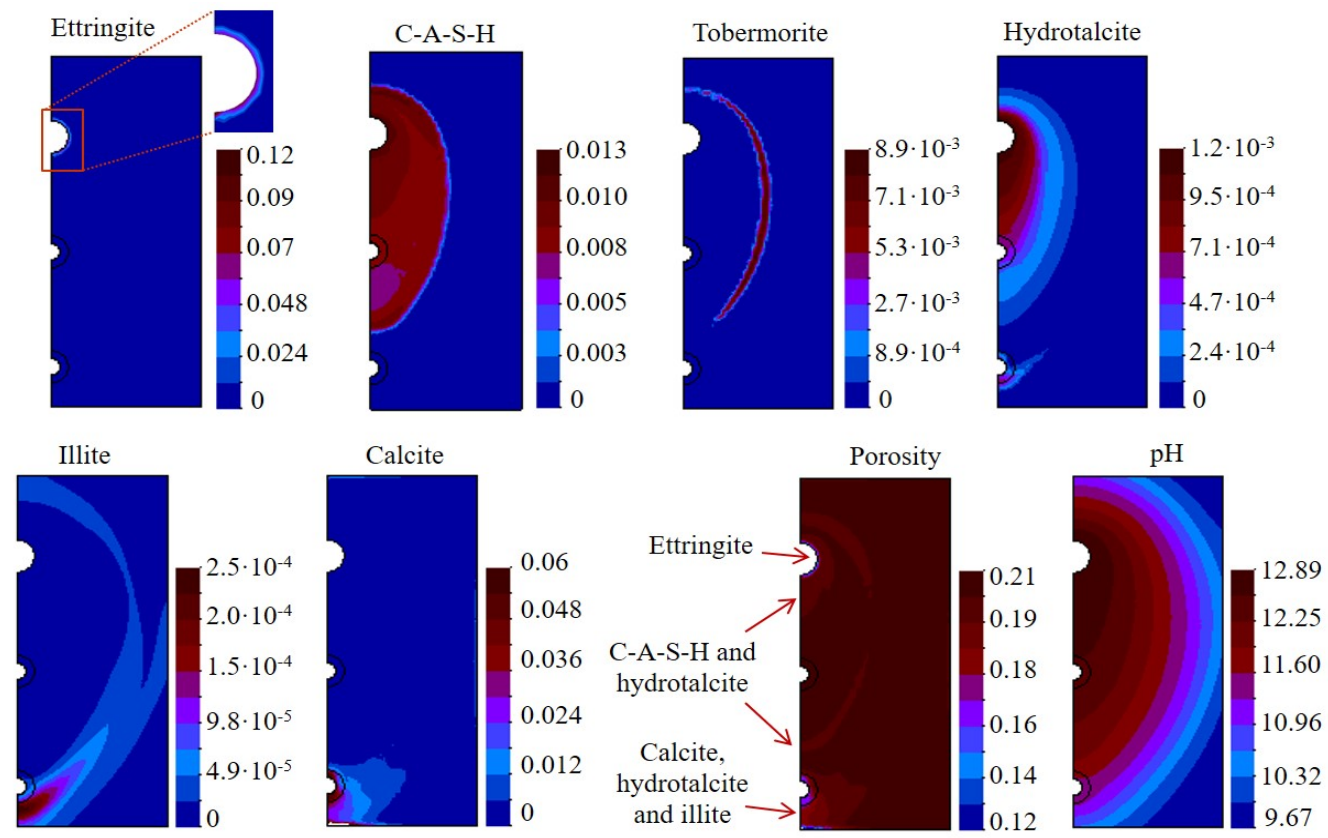

Figure 9: Variation of volumetric fraction $\left(\mathrm{m}^{3} \mathrm{~m}^{3}\right)$ of secondary minerals at the end of the experiment. Positive values mean precipitation. Variation of porosity and $\mathrm{pH}$ are also plotted. Dimensions are $1.7 \mathrm{~m} \times 0.7 \mathrm{~m}$.

A limited sensitivity analysis was performed by running a model includ- 
ing potential precipitation of zeolites and crystalline C-S-H phases (Figure 10). Only laumontite precipitated and the other considered zeolites and crystalline phases (analcime, natrolite, mordenite, wairakite, foshagite, gyrolite, okenite) did not precipitate. There was less precipitation of illite when laumontite is considered.

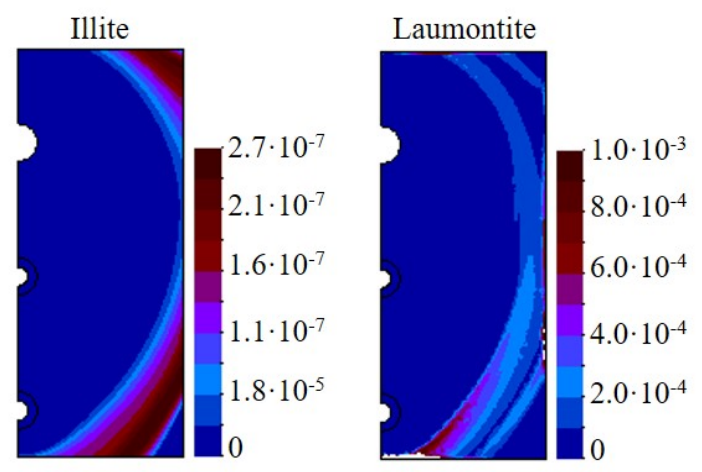

Figure 10: Variation of volumetric fraction of laumontite $\left(\mathrm{m}^{3} \mathrm{~m}^{3}\right)$ at the end of the experiment, for the mode that considers zeolites and C-S-H crystalline phases. Dimensions are $1.7 \mathrm{~m} \mathrm{x} 0.7 \mathrm{~m}$.

The high precipitation rate of calcite and consequent porosity reduction near the extraction borehole is quite remarkable. In order to analyse this properly, we performed a new calculation with a simplified chemical system with only one chemical reaction: calcite precipitation-dissolution at equilibrium $\left(\mathrm{CaCO}_{3}=\mathrm{Ca}^{2+}+\mathrm{CO}_{3}^{2}\right)$. When two waters are mixed with a different chemical composition but both in equilibrium with calcite, the mixed water tends to be supersaturated with respect to calcite (Figure 11a). As a result, calcite precipitates reducing $\mathrm{Ca}$ and $\mathrm{CO}_{3}$ concentrations in equal amounts (because of the stoichiometry of the reaction) until equilibrium is reached. We could calculate the new concentrations from the mixing ratio $(\lambda)$ and the chemical composition of the two end members (emplacement and Grimsel water):

$$
\left.\begin{array}{r}
u=c_{C a}-c_{C O_{3}}=\lambda\left(c_{C a, e m p}-c_{C O_{3}, e m p}\right)+(1-\lambda)\left(c_{C a, g r i}-c_{C O_{3}, g r i}\right) \\
c_{C a} c_{C O_{3}}=K_{c c}
\end{array}\right\}
$$




$$
\left.\begin{array}{c}
c_{C a}=\frac{1}{2}\left(u+\sqrt{u^{2}+4} K_{c c}\right) \\
c_{C O_{3}}=\frac{1}{2}\left(-u+\sqrt{u^{2}+4} K_{c c}\right)
\end{array}\right\}
$$

where $K_{c c}$ is the equilibrium constant for calcite dissolution-precipitation (unit activity coefficients assumed for simplicity). According to De Simoni et al. (2005), in the case of transport by advection and dispersion one can calculate the calcite precipitation rate, $r$, from

$$
r=\phi \frac{\delta^{2} c_{C a}}{\delta \lambda^{2}} \nabla \lambda^{T} \mathbf{D} \nabla \lambda
$$

where $\mathbf{D}$ is the dispersion-diffusion tensor and $c_{C a}$ is the Ca concentration. The rate depends on two factors: a chemical factor $\left(\frac{\delta^{2} c_{C a}}{\delta c_{C a}^{2}}\right)$ that can be calculated from equations 6 and 7 and a transport factor $\left(\phi \nabla \lambda^{T} \mathbf{D} \nabla \lambda\right)$ that can be calculated from the results of conservative transport. Figure 11 shows the calculations of calcite precipitation rate at the y-axis (axis crossing the three boreholes). The end-members are shown in Figure 11a together with the calcite equilibrium line $\left(c_{\mathrm{Ca}} c_{\mathrm{CO}_{3}}=K_{c c}\right)$. From this, one can calculate the chemical factor $\left(\frac{\delta^{2} c_{C a}}{\delta c_{C a}^{2}}\right)$ as a function of mixing ratio (Figure 11b). Our particular end-member concentrations give a high chemical factor for a low mixing ratio (i.e., much Grimsel water). Mixing ratios (Figure 11c) are taken from the numerical model with $\alpha_{L}=0.10 \mathrm{~m}$ and $\alpha_{T}=0.05 \mathrm{~m}$ at the end of the simulation. This gives high values for the transport factor near the emplacement and extraction boreholes (Figure 11d) due to the high concentration gradients, $\nabla \lambda$ (for the emplacement borehole) or high dispersion-diffusion coefficients, D, due to high velocity of water (for the extraction borehole). The chemical factor is lower at the center of the plume near the emplacement borehole where the mixing ratio is high (Figure 11e). Multiplication of both factors gives a high value near the extraction borehole, because there both the chemical and transport factors are high (Figure 11f). Of course, the chemical system is in reality much more complicated then just one reaction and other reactions have an impact too. However, calcite precipitation is controlled mainly by the mixing of the two types of water, and equation 8 and Fig. 11 can give a qualitative explanation of why we found such a high calcite precipitation near the extraction borehole. 

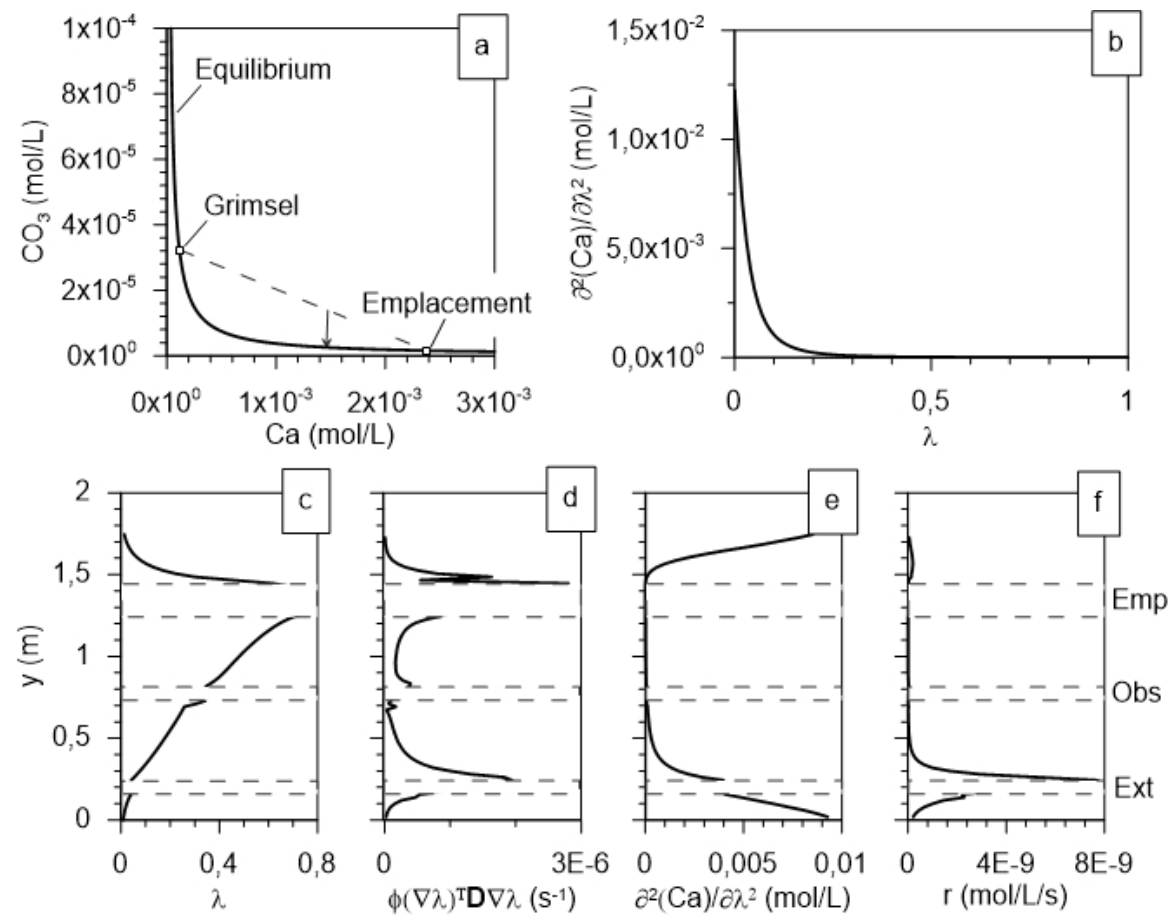

Figure 11: Calculation of calcite precipitation rate at the y-axis (axis crossing the three boreholes) assuming equilibrium calcite precipitation was the only reaction. Emp, obs and ext refer to emplacement, observation and extraction boreholes. 


\section{Conclusions}

The interaction of cement and rock at the Grimsel Test Site has been modelled. The conceptual model consisted of a simple flow system considering a homogeneous fracture and a chemical system for the interaction between the cement, groundwater and fault gouge filling the fracture. The modelling was performed in 2 steps. First, a 1D radial model simulating the emplacement borehole with the cement paste and the surrounding skin. Second, a 2D model starting at the emplacement borehole skin and including the two other boreholes (observation and extraction). The solution composition at the outer boundary of the 1D model was incorporated into the $2 \mathrm{D}$ model as a boundary condition. The changing flow conditions and the different volumes of water in the different boreholes were taken into account.

In both models, results showed that changes in flow rates (mainly emplacement) caused noticeable changes in concentrations in all boreholes, which was consistent with the observed oscillations in the measurements. Nevertheless, the monitored data showed more scattering. In addition, the model seemed to overestimate the effect of the alkaline plume at the observation borehole. These discrepancies could be attributed to simplifications in the models, such as a perfect mixing of the water in the emplacement borehole and a homogeneous fracture. Here we focused on the complexity of the geochemical system rather than that of the flow pattern.

Results from the 1D model showed dissolution of portlandite $(3 \mathrm{~mm})$, C-S-H gel and ettringite at the cement-gap interface, with a corresponding increase in porosity, mainly due to portlandite dissolution. Also there was precipitation of calcite and $\mathrm{C}-\mathrm{A}-\mathrm{S}-\mathrm{H}(\mathrm{Al} / \mathrm{Si}=0.05$ and $\mathrm{Ca} / \mathrm{Si}=1)$. At the gap there was precipitation of calcite due to the mixing between the Grimsel groundwater and the cement pore water. At the skin, primary minerals of the fault gouge (albite, K-feldspar, phlogopite, muscovite and quartz) dissolved. Ettringite, C-A-S-H, calcite, hydrotalcite and hydrogarnet precipitated causing a reduction of porosity. Dissolution of portlandite in the cement and precipitation of calcite at the cement-gap interface was observed in the postmortem analysis. Also $\mathrm{C}-\mathrm{A}-\mathrm{S}-\mathrm{H}(\mathrm{Al} / \mathrm{Si}=0.05$ and $\mathrm{Ca} / \mathrm{Si}=1)$ and calcite precipitation in the skin was observed in the mineralogical analysis of the overcore. However, ettringite precipitation in the skin was not found.

The results from the 2D model showed dissolution of primary minerals (albite, K-feldspar, quartz, muscovite and phlogopite) due to the increase in $\mathrm{pH}$ at the centre of the plume. Also there was precipitation of ettringite, 
very close to the emplacement borehole. There was precipitation of C-A-S-H $(\mathrm{Al} / \mathrm{Si}=0.05$ and $\mathrm{Ca} / \mathrm{Si}=1)$ in the centre of the plume, followed by a narrow zone of tobermorite precipitation. At the edge of the plume calcite and illite precipitated. This precipitation of calcite next to the extraction borehole, due to the more favorable mixing conditions between Grimsel groundwater and cement porewater, causes a $40 \%$ reduction in porosity. Results of an additional numerical model including zeolites, showed precipitation of laumontite, partially inhibiting the precipitation of illite.

\section{Acknowledgements}

The Long-Term Cement Studies (LCS) project was financed by the following agencies: Posiva (Finland), Japan Atomic Energy Agency (Japan), Radioacive Waste Management (UK), Swedish Nuclear Fuel and Waste Management Co. (Sweden) and Nagra (Switzerland). The funding for this modelling study from Posiva Oy and the discussions with the members of the LCS team are gratefully acknowledged.

\section{References}

De Simoni, M., Carrera, J., Sánchez-Vila, X., Guadagnini, A., 2005. A procedure for the solution of multicomponent reactive transport problems. Water Resources Research 41, W11410.

De Windt, L., Marsal, F., Tinseau, E., Pellegrini, D., 2008. Reactive transport modeling of geochemical interactions at a concrete/argillite interface, Tournemire site (France). Physics and Chemistry of the Earth 33, S295S305.

Gaucher, E., Blanc, P., Matray, J., Michau, N., 2004. Modeling diffusion of an alkaline plume in a clay barrier. Appllied Geochemistry 19, 1505-1515.

Hoch, A., Linklater, C., Noy, D., Rodwell, W., 2004. Modelling the interaction of hyperalkaline fluids with simplified rock mineral assemblages. Appllied Geochemistry 19, 1431-1451.

Kosakowski, G., Berner, U., 2013. The evolution of clay rock/cement interfaces in a cementitious repository for low- and intermediate level radioactive waste. Physics and Chemistry of the Earth 64, 65-86. 
Kulik, D. A., Kersten, M., 2001. Aqueous solubility diagrams for cementitious waste stabilization systems: II, end-member stoichiometries of ideal calcium silicate hydrate solid solutions. Journal of the American Ceramic Society 84, 3017-3026.

Kulik, D. A., Wagner, T., Dmytrieva, S. V., Kosakowski, G., Hingerl, F. F., Chudnenko, K. V., Berner, U. R., 2013. GEM-Selektor geochemical modeling package: revised algorithm and GEMS3K numerical kernel for coupled simulation codes. Computational Geosciences 17 (1), 1-24.

Lasaga, A. C., 1984. Chemical kinetics of water-rock interactions. Journal of Geophysical Research: Solid Earth 89 (B6), 4009-4025.

Mäder, U. K., Fierz, T., Frieg, B., Eikenberg, J., Rüthi, M., Albinsson, Y., Möri, A., Ekberg, S., Stille, P., 2006. Interaction of hyperalkaline fluid with fractured rock: Field and laboratory experiments of the HPF project (Grimsel Test Site, Switzerland). Journal of Geochemical Exploration 90 (1-2), 68-94.

Manette, M., Saaltink, M. W., Soler, J. M., 2015. GTS-LCS, in-situ experiment 2. modeling of tracer test 09-03. Tech. rep., POSIVA OY, Working Report 2015-05.

Martin, L. H. J., Leemann, A., Milodowski, A. E., Mäder, U. K., Münch, B., Giroud, N., 2016. A natural cement analogue study to understand the long-term behaviour of cements in nuclear waste repositories: Maqarin (Jordan). Applied Geochemistry 71, 20-34.

Marty, N. C. M., Tournassat, C., Burnol, A., Giffaut, E., Gaucher, E. C., 2009. Influence of reaction kinetics and mesh refinement on the numerical modelling of concrete/clay interactions. Journal of Hydrology 364, 58-72.

Matschei, T., Lothenbach, B., Glasser, F. P., 2007. Thermodynamic properties of portland cement hydrates in the system $\mathrm{CaO}-\mathrm{Al} 2 \mathrm{O} 3-\mathrm{SiO} 2-\mathrm{CaSO} 4-$ CaCO3-H2O. Cement and Concrete Research 37 (10), 1379-1410.

Moyce, E., Rochelle, C., Morris, K., Milodowski, A., Chen, X., Thornton, S., Small, J., Shaw, S., 2014. Rock alteration in alkaline cement waters over 15 years and its relevance to the geological disposal of nuclear waste. Appllied Geochemistry 50, 91-105. 
Myers, R. J., L'Hôpital, E., Provis, J. L., Lothenbach, B., 2015. Effect of temperature and aluminium on calcium (alumino)silicate hydrate chemistry under equilibrium conditions. Cement and Concrete Research 68, 83-93.

Nied, D., Enemark-Rasmussen, K., L'Hopital, E., Skibsted, J., Lothenbach, B., 2016. Properties of magnesium silicate hydrates (M-S-H). Cement and Concrete Research 79, 323-332.

Pfingsten, W., Paris, B., Soler, J. M., Mäder, U. K., 2006. Tracer and reactive transport modelling of the interaction between high-pH fluid and fractured rock: Field and laboratory experiments. Journal of Geochemical Exploration 90, 95-113.

Read, D., Glasser, F., Ayora, C., Guardiola, M., Sneyers, A., 2001. Mineralogical and microstructural changes accompanying the interaction of boom clay with Ordinary Portland Cement. Adv. Cem. Res. 13, 175-183.

Saaltink, M. W., Batlle, F., Ayora, C., Carrera, J., Olivella, S., 2004. Retraso, a code for modeling reactive transport in saturated and unsaturated porous media. Geologica Acta 2 (3), 235-251.

Saaltink, M. W., Soler, J. M., 2016. Grimsel Test Site - Long-Term Cement Studies. Reactive transport modeling of experiment 2 at Grimsel. Tech. rep., POSIVA OY, Working Report 2016-14.

Sánchez, L., Cuevas, J., Ramírez, S., Riuiz De León, D., Fernández, R., Vigil Dela Villa, R., Leguey, S., 2006. Reaction kinetics of FEBEX bentonite in hyperalkaline conditions resembling the cement-bentonite interface. Appl. Clay Sci. 33, 125-141.

Savage, D., Noy, D., Mihara, M., 2002. Modelling the interaction of bentonite with hyperalkaline fluids. Appllied Geochemistry 17, 207-223.

Savage, D., Soler, J. M., Yamaguchi, K., Walker, C., Honda, A., Inagaki, M., Watson, C., Wilson, J., Benbow, S., Gaus, I., Rueedi, J., 2011. A comparative study of the modelling of cement hydration and cement-rock laboratory experiments. Applied Geochemistry 26, 1138-1152. 
Soler, J. M., 2013. Reactive transport modeling of concrete-clay interaction during 15 years at the Tournemire Underground Rock Laboratory. European Journal of Mineralogy 25 (4), 639-654.

Soler, J. M., 2016. Two-dimensional reactive transport modeling of the alteration of a fractured limestone by hyperalkaline solutions at Maqarin (Jordan). Applied Geochemistry 66, 162-173.

Soler, J. M., Lasaga, A. C., 1998. An advection-dispersion-reaction model of bauxite formation. Journal of Hydrology 209 (14), 311-330.

Soler, J. M., Mäder, U. K., 2010. Cement-rock interaction: Infiltration of a high-pH solution into a fractured granite core. Geologica Acta 8 (3), 221-233.

Trapote-Barreira, A., Cama, J., Soler, J. M., 2014. Dissolution kinetics of CS-H gel: Flow-through experiments. Physics and Chemistry of the Earth 70-71, 17-31.

Wagner, T., Kulik, D. A., Hingerl, F. F., Dmytrieva, S. V., 2012. GEMSelektor geochemical modeling package: TSolMod library and data interface for multicomponent phase models. Canadian Mineralogist 50, 11731195 .

Wolery, T. J., Jackson, K. J., Bourcier, W. L., Bruton, C. J., Viani, B. E., Knauss, K. G., Delany, J. M., 1990. Current status of the EQ3/6 software package for geochemical modeling. Chemical Modeling of Aqueous Systems II, 104-116. 